Jurnal Ekonomi dan Industri

No. 1 Tahun Ke-XVIII, 2013

\title{
ANALISIS PENGARUH FAKTOR KEMAMPUAN DAN MOTIVASI TERHADAP KINERJA PRAJURIT DI LINGKUNGAN LANTAMAL II
}

\author{
Eddy Sanusi, $S^{*}$
}

\begin{abstract}
This research was intended to analyse the influence of factor of ability and motivation to soldier performance in Lantamal II environment.

The research used approach of Explanatory analysis. It means each variable which is presented at hypothesis will be observed through the test of causal relation between independent variable to dependent variable.

Method of data analyse that was used in this research was double linear regression which was obtained the equation of the following regression as follows: $\mathrm{Y}=24,850$ $+0,483 \mathrm{X}_{1}+0,321 \mathrm{X}_{2}$

Verification of hypothesis use statistical test by simultan ( $\mathrm{F}$ test) with significant value 0,000 for alpha $5 \%$ and have influence $84,4 \%$, so there is other factor equal to $15,6 \%$ which influence to soldier performance. For ability variable have influence equal to $86,7 \%$ and t significant 0,000 for alpha $5 \%$ and for the motivation variable have influence equal to $68,7 \%$ with t significant 0,000 for alpha $5 \%$.

Based to result of analysis indicate that at significant level 5\%, ability and motivation simultaneously have positive influence and significant to soldier performance in Lantamal II environment, and likewise partially variable of ability and motivation have positive influence at significant level 5\%.
\end{abstract}

Kata kunci: Kemampuan, motivasi dan kinerja

\section{PENDAHULUAN}

Gelombang reformasi Mei 1998 memaksa ABRI mengadakan perubahan internal dalam organisasi hingga paradigmanya.Beberapa langkah awal reformasi organisasi TNI adalah mengubah nama ABRI menjadi TNI, kemudian diikuti dengan langkah restrukturisasi dan reorganisasi TNI.Bukan saja TNI tetapi organisasi lainnya pun menghadapi tekanantekanan dan memaksa organisasi tersebut pada lingkungan yang serba tidak pasti. Kita tak dapat memperkirakan dengan mudah apa yang akan terjadi dihari esok, segalanya serba tidak menentu, akan tetapi kondisi ini tidak bisa dihindari. Kata Peter Drucker (1998), kita hidup diera yang diskontinyu. Apa yang terjadi hari ini belum tentu merupakan rentetan atau sambungan peristiwa kemarin, dan mungkin tidak akan menjadi bagian dihari esok. Kondisi ini dipicu oleh adanya perubahan lingkungan yang sangat cepat disertai kemajuan teknologi dan sistem teknologi dan sistem informasi yang juga begitu cepat.Globalisasi telah melanda dunia dan ini mempunyai pengaruh terhadap kehidupan bermasyarakat, berbangsa dan

\footnotetext{
${ }^{*}$ Eddy Sanusi, S adalah dosen tetap Fakultas Ekonomi Universitas Krisnadwipayana, Jakarta
} 
bernegara, termasuk dalam kehidupan keprajuritan di lingkungan TNI.Pengaruh tersebut membawa perubahan kehidupan prajurit baik positif maupun negatif, yang perlu disikapi oleh kita bersama, sehingga pengaruh negatif dapat ditangkal dan diminimalisir.Dalam organisasi kemiliteran untuk mencapai tujuan organisasi, dibutuhkan sumber daya manusia prajurit yang professional.Realita dinamika sistem kehidupan global dan nasional tersebut di atas merupakan gambaran atas proses penyempurnaan tata nilai lama ke dalam tata nilai nilai baru yang diharapkan akan lebih baik, terutama dalam pemberian motivasi kerja dan kinerja prjurit TNI AL dalam menghadapi setiap panggilan tugas di masa depan sesuai dengan visi yang telah ditentukan TNI AL.

Komando Armada RI Kawasan Barat sebagai salah satu komando utama TNI AL merupakan bagian dari pelaksanaan tugas pokok TNI dalam melaksanakan pemberdayaan wilayah pertahanan di wilayah Indonesia bagian barat dengan batas wilayah kerja dari perairan utara Tegal ke barat sampai perairan Sabang di Provinsi NAD.Pangkalan Utama TNI AL II (Lantamal II) mempunyai 2 (dua) tugas pokok yaitu; 1) Selaku Kolakduk Koarmabar, 2) Selaku Satgaskamla III.Kolakduk Koarmabar mempunyai tugas pokok adalah menyelenggarakan dukungan logistik dan administrasi bagi unsur-unsur TNI AL, pembinaan potensi nasional menjadi kekuatan pertahanan keamanan negara dibidang maritim, serta pembinaan teritorial matra laut serta tugas-tugas lain berdasarka kebijakan Kasal.Selaku Satgaskamla III mempunyai tugas di wilayahnya dan menigkatkan daya guna dan hasil guna unsur-unsur secara optimal dalam pelaksanaan operasi keamanan laut.

Untuk menunjang tugas pokok Lantamal II dalam melaksanakan pertahanan matra laut, diperlukan penyiapan sumber daya manusia (SDM) untuk dipersiapkan sebagai prajurit TNI AL yang mengawaki satuan kerja dijajaran Koarmabar yang direkrut dari masyarakat umum melalui standar selektifitas yang telah ditetapkan untuk didik dan dilatih melalui latihan dasar kemiliteran sesuai dengan stara/penggolongan tingkat perwira, bintara atau tamtama.

Prajurit TNI AL yang telah bertugas secara definitif dijajaran Koarmabar secara berjenjang dan berlanjut akan mendapat promosi bagi peningkatan karir dan kepangkatannya, sehingga dalam perkembangannya setiap prajurit akan memperoleh peningkatan profesionalisme atau kinerja dalam waktu yang telah ditentukan. Untuk memudahkan bagi peningkatan kinerja prajurit TNI AL di lingkungan Lantamal II maka salah satu upaya dengan meningkatkan kemampuan dan lebih menumbuhkan motivasi kerja para prajurit yang dapat dilaksanakan di Lantamal II

Profesionalisme prajurit dalam upaya mendukung tugas haruslah selalu dipelihara dan ditingkatkan melalui pendidikan, latihan dan pembinaan yang dilaksanakan terus menerus.Profesionalisme prajurit TNI AL khususnya prajurit di lingkungan Lantamal II sangat dipengaruhi oleh motivasi kerja yang meliputi kepuasan dan ketidakpuasan kerja, "skill" ataupun kemampuan yang dipengaruhi oleh ilmu pengetahuan dan kegiatan latihan yang dilaksanakan serta variabel lain berupa disiplin, herarki dan kehormatan Militer.

Kepuasan kerja (job satisfaction) prajurit merupakan faktor penting dalam manajemen sumber daya manusia, karena secara langsung maupun tidak langsung akan mempengaruhi profesionalisme prajurit.Suatu gejala yang dapat membuat rusaknya kondisi organisasi adalah rendahnya kepuasan kerja prajurit dimana timbul gejala seperti kemangkiran, malas bekerja, banyakan keluhan prajurit, rendahnya prstasi kerja, indisipliner prajurit dan gejala negatif lainnya.Sebaliknya kepuasan yang tinggi sangat diinginkan oleh pemimpin TNI AL khususnya di lingkungan Lantamal II karena dapat dikaitkan dengan hasil positif yang mereka harapkan. 
Tujuan penulisan ini adalah untuk mengetahui Pengaruh Faktor Kemampuan dan Motivasi Terhadap Kinerja Prajurit Di Lingkungan Lantamal II

\section{KERANGKA TEORI}

Beberapa ahli telah mencoba mengemukakan definisi Manajemen Sumber Daya Manusia, walaupun definisi yang dikemukakan terlihat berbeda tetapi pada dasarnya sama. Beberapa pendapat dan para ahli tersebut antara lain: Menurut H. Hadari Nawawi (2003) "Manajemen Sumber Daya Manusia adalah proses mendayagunakan manusia sebagai tenaga kerja secara manusiawi, agar potensi fisik dan psikis yang dimilikinya berfuingsi maksimal bagi pencapaian tujuan organisasi (perusahaan)". Berbeda lagi menurut Edwin B. Filippo (2000) "MSDM adalah perencanaan, pengorganisasian, pengarahan dan pengawasan kegiatankegaiatan pengadaan, pengembangan, pemberian kompensasi, pengintegrasian pemeliharaan dan pelepasan sumber daya manusia agar tercapai berbagai tujuan individu, organisasi dan masyarakat". Definisi ini menggabungkan fungsi-fungsi manajemen dan fungsi-fungsi operatif di bidang personalia.

\section{Fungsi Manajemen Sumber Daya Manusia}

Fungsi operasional terdiri dari: a) Pengadaan (Procurement); adalah proses penarikan, seleksi, penempatan, orientasi dan induksi. Untuk mendapatkan karyawan yang sesuai dengan kebutuhan perusahaan, pengadaan yang baik akan membantu terwujudnya tujuan perusahaan. b) Pengembangan (Development); adalah proses peningkatkan keterampilan teknis, teoritis, konseptual dan moral karyawan melalui pendidikan dan pelatihan, pendidikan dan latiahn yang diberikan harus sesuai dengan pekerjaan masa kini maupun masa depan. c) Kompensasi (Compensation); adalah proses balas jasa langsung (direct) dan tidak langsung (indirect) uang atau barang kepada karyawan sebagai imbal jasa yang diberikannya kepada perusahaan. Prinsip kompensasi adalah adil dan layak. d) Pengintegrasian (Integration); adalah kegiatan untuk mempersatukan kepentingan perusahaan dan kebutuhan karyawan agar tercipta kerja sama yang serasi dan saling menguntungkan. Perusahaan memperoleh laba, karyawan dapat memenuhi kebutuhan dan hasil pekerjaannya. Pengintegrasian merupakan hal yang sulit dan penting karena mempersatukan dua kepentingan yang bertolak belakang. e) Pemeliharaan (Maintenance); adalah kegiatan untuk memelihara dan meningkatkan kondisi fisik, mental dan loyalitas karyawan, agar mereka tetap mau bekerja sama sampai pensiun. f) Kedisiplinan (Discipline); merupakan fungsi Manajemen Sumber Daya Manusia yang terpenting dan kunci terwujudnya tujuan yang maksimal. Kedisiplinan adalah keinginan dan kesadaran untuk mentaati peraturan-peraturan perusahaan dan norma-norma sosial. g) Pemberhentian (Separation); adalah putusnya hubungan kerja seseorang dan suatu perusahaan, pemberhentian ini disebabkan oleh keinginan perusahaan, kontak kerja berakhir, pensiun dan oleh sebab lainnya.

Pengertian Kemampuan; Menurut Samsi Haryanto (2003), pada dasarnya jiwa manusia dapat dibedakan menjadi dua aspek, yakni aspek kemampuan (ability) dan aspek kepribadian (personality).Aspek kemampuan meliputi: prestasi belajar, intelegensi, dan bakat; sedangkan aspek kepribadian meliputi watak, sifat, penyesuaian diri, minat sikap, dan motivasi. 
Kemungkinan besar kinerja karyawan yang tinggi dicapai bila manajemen telah memastikan sejauh mana suatu pekerjaan menuntut masing-masing dari kemampuan itu dan kemudian menjamin bahwa karyawan dalam pekerjaan tersebut mempunyai kemampuan-kemampuan tersebut.Kinerja karyawan dapat ditingkatkan bila terdapat kesesuaian antara pekerjaan dengan kemampuan.Kemampuan intelektual atau fisik yang khusus yang diperlukan untuk kinerja yang memadai pada suatu pekerjaan bergantung pada persyaratan kemampuan dan pekerjaan itu. Bila kesesuaian pekerjaan-kemampuan tidak sinkron karena karyawan mempunyai kemampuan yang jauh melampaui persyaratan dan pekerjaan itu, maka kemungkinanan besar kinerja pekerjaan akan memadai, tetapi akan ada ketidak efisienan organisasional dan mungkin kemerosotan dalam kepuasan kerja karyawan.Menurut Malayu SP Hasibuan (2002), ability (kemampuan) adalah menunjukan potensi orang untuk melaksanakan pekerjaan, mungkin kemampuan itu dimanfaatkan atau mungkin juga tidak. Kemampuan berhubungan erat dengan kemampuan fisik dan mental yang dimiliki orang untuk melaksanakan pekerjaan dan bukan yang ingin melaksanakannya.Menurut Suyadi Prawirosentono (2004), secara sederhana kemampuan seseorang dapat dilihat dan keahlian atau skill yang dimiliki seseorang. Keahlian tersebut dipengaruhi oleh latar belakang pendidikan dan pengalaman. Menurut Dennis C. Kinlaw (A. Dale Timpe, 2004), kemampuan merupakan ciri rumit yang terdiri dan kecakapan alamiah, kepercayaan, pengetahuan serta keterampilan untuk melaksanakan pekerjaan yang bersangkutan.Sedangkan menurut Hinrichs, J.R. (2004), kemampuan adalah merupakan kemahiran/keahlian seorang karyawan untuk melakukan suatu pekerjaan. Hal itu akan mempengaruhi kinerja dan produktivitas. Kemampuan yang dibawa oleh karyawan ke tempat kerja berupa : keterampilan (skill), pengetahuan, kecakapankecakapan interpersonal serta kecakapan-kecakapan teknis. Para karyawan yang tidak memiliki hal tersebut yang diperlukan untuk melakukan suatu pekerjaan, mungkin tidak mampu menghasilkan kinerja yang balk (Snell, S.A. \& Wexley, K.N., 2004).

\section{Aspek - Aspek Kemampuan}

Aspek-aspek kemampuan terdiri dan : prestasi belajar, intelengensi, dan bakat. Menurut Pandji Anaroga \& Sri Suyati (2004): Mob. As'ad (1998), intelegensi diberi batasan sebagai kemampuan untuk menyesuaikan din dengan sebaik-baiknya terhadap lingkungan. Oleh karena itu, tingkat intelegensi seseorang sangat menentukan kesuksesannya bekerja. Orang yang intelegensinya tinggi sanggup memecahkan kesulitan yang dihadapinya dalam bekerja, dan demikian pula sebaliknya.Sedangkan bakat ialah kemampuan dasar yang menentukan sejauh mana kesuksesan individu untuk memperoleh keahlian atau pengetahuan tertentu. Jadi apabila seseorang mempunyai bakat mekanik, bila diberi latihan tentang mekanik dia akan mudah untuk menguasai masalah mekanik dan sebaliknya. Di dalam bekerja, bakat-bakat yang sesuai dengan pekerjaannya sangat dibutuhkan. Hal ini disebabkan untuk masing-masing pekerjaan seringkali dituntut bakat yang berbeda-beda pula. Dengan adanya kesesuaian antara bakat dan pekerjaannya maka pekerjaanya menjadi Iebih berhasil. Selanjutnya dikemukakan bahwa perpaduan antara bakat dan minat dapat menentukan tingkat prestasi kerja seseorang. Adapun minat adalah sikap yang membuat orang senang terhadap objek, situasi, atau ide-ide tertentu. Hal ini diikuti oleh perasaan senang dan kecenderungan untuk mencari obyek yang disenangi itu. Pola-pola minat seseorang merupakan salah satu faktor yang menentukan kesesuaian orang dengan pekerjaannya. 


\section{Jenis-Jenis Kemampuan}

Dalam konteks organisasi, kemampuan ini mungkin meliputi kepandaian memotivasi orang lain, mempengaruhi orang lain, memimpin orang lain, membangkitkan semangat tim, membereskan konflik dan sebagainya. Kemampuan konseptual mencakup kemampuan untuk melihat perusahaan secara keseluruhan. Ia mencakup pengertian bagaimana berbagai fungsi organisasi saling bergantung dan bagaimana perubahan pada satu bagian mempengaruhi seluruh bagian lain, dan ia mencakup pula visualisasi hubungan antara usaha perorangan dengan industri, masyarakat, dan kekuatan-kekuatan politis, sosial dan ekonomis negara sebagai keseluruhan. Keterampilan-keterampilan konseptual juga meliputi kemampuan memvisualisasikan han depan organisasi dan visinya terhadap han depan organisasi itu.Menurut Stephen P. Robbins (2002), kemampuan-kemampuan keseluruhan dan seorang individu pada hakekatnya tersusun dan dua perangkat faktor: kemampuan intelektual dan kemapuan fisik. Kemampuan intelektual adalah kemampuan yang diperlukan untuk menjalankan kegiatan mental. Tujub dimensi yang paling sering dikutip yang menyusun kemampuan intelektual adalah kemahiran berhitung (kecerdasan numeris), pemahaman verbal, kecepatan perseptual, penalaran induktif, penalaran deduktif, visualisasi ruang, dan ingatan (memori).Menurut Rush Syarif (2002), jenis-jenis kemampuan antara lain meliputi: kecerdasan menaganalisis, prakarsa, bijaksana, mengambil keputusan organisasi, pengetahuan tentang pekerjaan, komunikasi, kepemimpinan. Menurut Katz (dalam Syafaruddin Aiwi; 2001) terdapat tiga katagori kemampuan SDM yaitu : kemampuan dan keahhian yang bersifat konseptual (conceptual skill), keahlian yang bersifat "human" (human skill), dan keahlian yang bersifat teknika! (technical skill). Keahlian konseptual menyangkut kemampuan individu dalam organisasi dalam berbagai fungsi manajerial seperti pengambilan keputusan, penyelesaian konflik dan problem yang kompleks, penyusunan strategi dan kebijakan. Keahlian yang bersifat human seperti terlihat pada kemampuan bekerja sama, interrelationship, komunikasi dalam kelompok. Keahhian yang bersifat teknikal adalah kemampuan individu yang lebih bersifat keahhian khusus teknik operasional seperti mengoperasikan alat-alat dan kegiatan-kegiatan yang bersifat administratif lainnya.

\section{Faktor-faktor yang mempengaruhi kemampuan.}

Menurut Hadari Nawawi (2003), pelatihan dan pengembangan mempengaruhi kemampuan kerja. Pelatihan fokus kegiatannya untuk meningkatkan kemampuan kerja dalam memenuhi kebutuhan tuntutan cara bekerja yang paling efektif pada masa sekarang; sedangkan pengembangan sebagai usaha membantu para pekerja agar menguasai berbagai kemampuan yang dibutuhkan organisasi/perusahaan untuk melaksanakan pekeijaan secara efektif dan efisien di masa mendatang. Menurut T Hani Handoko (2003), program latihan dan pengembangan mempengaruhi kemampuan kerja karyawan. Latihan dan Pengembangan dilakukan untuk menutup "gap" antara kecakapan atau kemampuan karyawan dengan permintaan jabatan dan program-program tersebut diharapkan dapat meningkatkan efisiensi dan efektifitas kerja karyawan dalam mencapai sasaran-sasaran kerja yang telah ditetapkan.

Berdasarkan penjelasan di atas, maka dapat disimpulkan bahwa kemampuan individu karyawan ditentukan oleh fakor-faktor sebagai berikut - faktor pendidikan yang ditempuh, faktor pelatihan yang diikuti, faktor pengalaman kerja. Faktor Pengalaman adalah pengalaman bekerja pegawai. Teknik pengukuran tinggi rendahnya pengalaman berdasarkan angka tahun lamanya bekerja dan data yang diperoleh merupakan data ratio. Sedangkan Faktor Pelatihan 
adalah pelatihan atau kursus -kursus yang pernah diikuti pegawai yang sesuai dengan bidang pekerjannya. Teknik pengukuran tinggi rendahnya pelatihan berdasarkan banyaknya pelatihan atau kursus-kursus yang diikuti dan data yang diperoleh merupakan data ratio.

\section{Faktor Motivasi}

Pendapat yang dikemukakan oleh Handoko (2003) tentang pengertian motivasi adalah: "Motivasi diartikan sebagai keadaan dalam pribadi seseorang yang mendorong keinginan individu untuk melakukan kegiatan kegiatan tertentu guna mencapai tujuan".Selanjutnya Siagian (2002), mendefinisikan motivasi adalah keseluruhan proses motif bekerja pada karyawan sedemikian rupa sehingga mau bekerja dengan ikhlas demi tercapainya tujuan organisasi dengan efisien dan ekonomis. Dari definisi tersebut di atas dapat disimpulkan bahwa motivasi merupakan suatu keinginan yang timbul dan pribadi seseorang untuk melakukan kegiatan-kegiatan agar tercapai suatu tujuan Atas dasar hal itulah motivasi sangat diperlukan dalam memberikan semangat kepada karyawan. Untuk lebih memperkuat tentang teori motivasi di atas, benikut ini disampaikan beberapa teori dan sekian banyak teori motivasi yang dikemukakan oleh beberapa ahli. Adapun teori-teori motivasi yang dimaksud adalah sebagai berikut: (1) Teori Abraham H. Maslow, Dalam teorinya, Maslow berpendapat bahwa apabila kebutuhan pada tingkat bawah telah dipenuhi, maka akan timbul kebutuhan lain yang Iebih tinggi yang harus terpenuhi. Secara terperinci kelima kebutuhan dasar manusia yang membentuk hirarki kebutuhan adalah: a) Kebutuhan fisiologis, yaitu kebutuhan untuk hidup terus seperti makan, minum, pemmahan, tidur dan sebagainya; b) Kebutuhan keamanan, yaitu kebutuhan akan keselamatan dan perlindungan dan bahaya, ancaman dan perampasan ataupun pemecatan dan pekerjaan; c) Kebutuhan sosial, yaitu kebutuhan akan rasa cinta dan kepuasan dalani menjalin hubungan dengan orang lain, kepuasan dan perasaan memiliki serta ditenima dalam suatu kelompok, rasa kekeluargaan dan persahabatan; d) Kebutuhan penghangaan, yaitu kebutuhan akan status dan kedudukan, kehormatan diri reputasi dan produktivitas; e) Kebutuhan aktualisasi diri, yaitu kebutuhan pemenuhan diri, untuk menggunakan potensi diri pengembangan din semaksimal mungkin, kreativitas serta menyelesaikan. James A. F. Stoner (Susilo Martoyo, 2004) membuat urutan atau hirarki kebutuhan dan Maslow di atas sebagai berikut:

Gambar - 1: Hirarki Kebutuhan dan Maslow

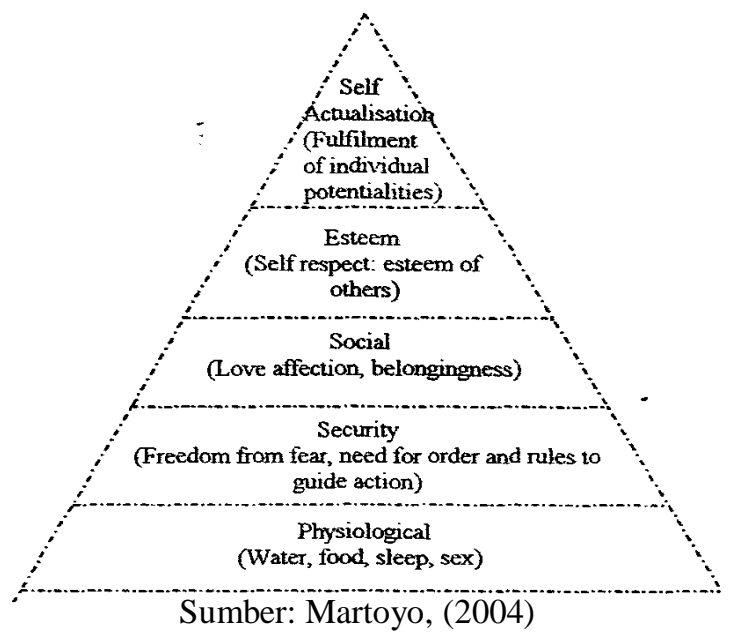


Berdasarkan uraian dan gambar di atas, dapat disimpulkan bahwa tingkah laku atau tindakan masing-masing individu pada suatu saat tertentu, biasanya ditentukan oieh kebutuhan yang paling mendesak di mana individu terdorong untuk berusaha.Oleh karena itu setiap manajer yang ingin memotivasi para karyawan perlu memiliki hirarki kebutuhan-kebutuhan manusia. (2) Teori Frederick Herzberg; Berdasarkan hasil penelitiannya Herzberg (2000) menyimpulkan bahwa ada dua kelompok faktor yang mempengaruhi motivasi kerja seseorang dalam organisasi yaitu: a) Faktor motivator atau pemuas, Faktor yang mempunyai pengaruh untuk meningkatkan produktivitas kerja atau kepuasan keija, seperti produktivitas, penghargaan, tanggungjawab, kemajuan dan peningkatan. Dengan kata lain faktor menyentuh manusia melalui rasa senang/cinta dan tidak senang/cinta bekerja dan dapat meningkatkan dan menurunkan produktivitas kerja; b) Faktor Iklim Baik atau Pemeliharaan. Faktor yang' diperlukan untuk mempertahankan tingkat yang paling rendah yaitu "tidak adanya ketidakpuasan”. Faktor ini mencakup gajilupah, jaminan kerja, kondisi kerja, dan status. Dengan kata lain yang menyentuh manusia melalui rasa puas dan tidak puas dalam pekerjaannya, karena itu menyangkut lingkungan kerjaannya.

\section{Kinerja Prajurit (Performance)}

Kinerja seseorang merupakan kombinasi dan kemampuan. usaha dan kesempatan yang dapat dinilai dan hasil kerjanya, (Bernardin, 2002). Lebih lanjut Bemardin menjelaskan kinerja merupakan catatan outcome yang dihasilkan dan fungsi prajurit tertentu atau kegiatan yang dilakukan selama periode waktu tertentu. Sedang kinerja suatu jabatan secara keseluruhan sama dengan jumlah (rata-rata) dan kinerja fungsi anggota atau kegiatan yang dilakukan. Pengertian kinerja disini tidak bermaksud menilai karakteristik individu tetapi mengacu pada serangkaian hash yang diperoleh selama penode waktu tertentu.

Pada umumnya prestasi kerja atau kinerja (performance) diberi batasan oleh Maier sebagai kesuksesan seseorang dalam melaksanakan suatu pekerjaan. Lebih tegas lagi Porter clan Lawler menyatakan bahwa kinerja adalah "successful role achievement " yang diperoleh seseorang dan perbuatannya (As'ad; 2001). Dan batasan-batasan tersebut jelaslah bahwa yang dimaksud dengan prestasi kerja adalah basil yang dicapai seseorang menurut ukuran yang berlaku untuk pekerjaan yang bersangkutan.

\section{Faktor-Faktor yang Mempengaruhi Kinerja}

Para pimpinan organisasi sangat menyadari adanya perbedaan kinerja antara seorang anggota dengan anggota yang lainnya yang berada di bawab pengawasannya. Walaupun anggota prajurit bekerja di tempat yang sama namun produktivitas mereka tidak.

Menurut Gibson ,et.al. (2002), ada tiga perangkat variabel yang mempengaruhi perilaku dan kinerja, yaitu: 1) Variabel individu, terdiri dari: a) Kemampuan dan keterampilan; Mental dan fisik, dimaksudkan sebagai tingkat kondisi individu prajurit dalam menunjang kemampuan dan keterampilan yang dimilikinya, sehingga prajurit tersebut dapat berprilaku sesuai dengan yang dibutuhkan organisasi. b) Latar belakang Keluarga, tingkat sosial, pengalaman. Faktor-faktor ini sangat menunjang prestasi kerja (kinerja) prajurit di dalam pelaksanakan pekerjaan. c) Demografis Umur, asal usul, jenis kelamin. Usia yang produktif, daerah asal prajurit dan jenis kelamin secara demografis sangat berperan dalam menunjang prestasi kerja prajurit. 2) Variabel Organisasi, Dalam upaya menunjang keberhasilan prajurit 
melaksanakan tugas dan kewajibannya di tempat kerja. Prajurit tersebut hams ditunjang dengan sumber daya yang dimiliki organisasi, tingkat kepemimpinan, sistem imbalan, struktur organisasi dan desain pekerjaan. 3) Variabel Psikologis, terdiri dari: Secara psikologis, prajurit dapat berprilaku dan berprestasi sesuai dengan yang diharapkan organisasi, jika prajurit tersebut memiliki persepsi yang baik organisasi, sikap dan kepribadian yang sesuai dengan kondisi pekerjaan, adanya proses pembelajaran secara kontinyu dan memiliki motivasi yang tinggi.

Lain pula halnya dengan pendapat Stoner dan Freeman (2000), mereka mengemukakan tiga hal yang mempengaruhi prestasi kerja seseorang, yaitu: motivasi, kemampuan dan persepsi peran, ketiganya saling berhubungan, bila salah satu faktor penghambat prestasi kerja tinggi, maka prestasi kerja ada kemungkinan rendah meskipun kedua faktor lain mendorong prestasi kerja.

Menurut Tiffin dan McCormick (2000), ada dua variabel yang mempengaruhi prestasi kerja atau produktivitas kerja seseorang yaitu, 1) Variabel individual, meliputi sikap karakteristik, kepribadian, sifat-sifat fisik, minat dan motivasi, pengalaman, umur, jenis kelamin, pendidikan serta karakteristik individual lainnya. 2) Variabel situasional, terdiri dari: a) Faktor fisik dan pekerjaan, meliputi metode kerja, kondisi dan desain perlengkapan kerja, penataan ruang dan lingkungan fisik (penyinaran, temperatur dan ventilasi); b) Faktor sosial dan organisasi, meliputi peraturan-peraturan organisasi, sifat organisasi, jenis latihan dan pengawasan, sistem upah dan lingkungan sosial.

\section{Penilalan Kinerja}

Menurut Handoko. H (2004), penilaian prestasi kerja adalah proses melalui organisasiorganisasi yang mengevaluasi atau menilai prestasi kerja prajurit. Kemudian menurut Hasibuan (2000), penilaian prestasi kerja didefinisikan sebagai suatu kegiatan untuk menilai rasio hasil kerja nyata dengan standar baik kualitas, maupun kuantitas yang dihasilkan setiap individu prajurit. Dengan demikian keinginan prajurit dalam hal promosi, kenaikan gaji, lingkungan kerja yang baik, tempat yang berprestise, dan kepuasan bekerja, tidak akan diberikan begitu saja oleh organisasi. Untuk mencapai hal itu harus ada feed-back antara prajurit dan organisasi.

Tidak semua keinginan prajurit tersebut dapat dipenuhi oleh Instansi organisasi, kemungkinan hanya sebagian saja yang diterima oleh prajurit. Tergantung dan besar-kecilnya kontribusi yang dapat diberikan prajurit kepada organisasi. Biasanya para Pimpinan organisasi berusaha untuk memilih prosedur yang akan meminimalkan konflik yang ada pada prajurit. Prajurit dan Organisasi harus memberikan umpan balik yang relevan demi tercapainya tujuan organisasi.

Dalam pelaksanaannya, implementasi penilaian kinerja prajurit perlu memperhatikan tentang siapa yang melakukan penilalan kinerja dan segenap prajurit. Simamora (2002) mengemukakan ada beberapa komponen yang dapat menilai kinerja para prajurit, yakni: 1) Atasan langsung; Tatanan hierarkis dan otoritas formal di sebagian besar organisasi membenikan legitimasi kepada atasan untuk mengevaluasi bawahan- bawahannya. Atasan langsung bekerja sangat erat dengan bawahan yang dievaluasi dan seharusnya merupakan orang yang mempunyai pandangan yang paling lengkap dan kinerja sehari-hari seorang prajurit. Atasan kemungkinan yang paling akrab dengan kinerja individu, dan dalam sebagian besar pekerjaan telah memiliki kesempatan yang paling baik untuk mengamati kinerja 
pekerjaan aktual. Lebih jauh lagi atasan langsung kemungkinan paling mampu mengkaitkan kinerja individu terhadap tujuan departemental dan tujuan organisasi. Karena dia juga bertanggung jawab atas keputusan pemberian imbalan ataupun hukuman, tidaklah mengherankan bahwa umpan batik dan atasan sangat berkaitan dengan kinerja dibandingkan dan sumber-sumber yang lain. Selain itu atasan biasanya mengemban tanggung jawab atas pengelolaan unit tertentu. Apabila tugas mengevaluasi bawahan diserahkan pada orang lain, otontas bawahan dapat terkikis secara serius. Oleh karenanya atasan langsung paling memenuhi syarat, untuk memberikan informasi yang paling relevan mengenai kinerja, kelemahan dan potensi prajurit. Kerugian utama dalam penggunaan atasan langsung sebagai satu-satunya penilaian adalah bias atasan, konflik kepribadian atau persahabatan yang dapat mencegah penilaian objektif. 2) Atasan lebih tinggi. Di dalam banyak organisasi seorang atasan tingkat atas akan memeniksa dan melengkapi evaluasi yang dibuat oleh atasan langsung si prajurit. Pengguna opini setuju atau menolak oleh seorang atasan yang lebih tinggi dapat menghilangkan bias tertentu yang dijumpai dalam penilaian kinerja. Hal ini benar bila biasanya jika prajurit dan atasan langsung telah mengembangkan ikatan pribadi yang erat ataupun konflik kepribadian yang membuat sulit bagi atasan langsung agar membuat evaluasi kinerja prajurit lebib jauh lagi, seorang prajurit, kecil kemungkinannya merasa bahwa gaji dan prospek promosinya benar-benar dibawah kendali atasan langsung. Jika seorang atasan yang lebih tinggi juga mempengaruhi proses penilaian kinerja. 3) Rekan Sejawat, Rekan sejawat dan kolega sering mampu mengevaluasi fase tertentu dan kinerja prajurit yang tidak dapat dievaluasi oleh atasan. Kontribusi terhadap pekerjaan pada proyek kelompok, efektifitas antar pribadi, kemampuan berkomunikasi, reabilitas, dan inisiatif merupakan faktor-faktor yang dapat dinilai oleh rekan prajurit. Kedekatan hubungan kerja dan jumlah kontrak pribadi kerap menempatkan rekan sejawat dalam suatu posisi membuat penilaian kinerja yang akurat. Dalam beberapa pekerjaan seperti penjualan diluar organisasi/perusahaan, distributor produk, tenaga wiraniaga atasan langsung, kemungkinan jarang dapat mengamati kinerja pekerjaan aktual seorang bawahannya. Kadang-kadang indikator tujuan seperti unit yang dijual dapat memberikan informasi yang berguna yang berkaitan dengan kinerja, tetapi dalam keadaan lainnya penilaian dan rekan sejawat bahwa lebih baik. Rekan sejawat dapat memberikan suatu perspektif terhadap kinerja yang berbeda dan atasan langsung. Meskipun demikian, untuk mengurangi kemungkinan bias persahabatan pada saat secara bersamaan, meningkatkan nilai umpan balik dan informasi yang diberikan, adalah penting menentukan secara.rinci apa yang akan dievaluasi o!eh rekan sejawat, sebagai contoh, "kualitas bantuannya pada masalahmasalah teknis". Pada umumnya, evaluasi penilaian kinerja oleh rekan sejawat digunakan untuk melengkapi penilaian atasan langsung. Sayangnya persahabatan, rasa dengki dan frekwensi interaksi semuanya tampak mempengaruhi evaluasi rekan sejawat. Lebih jauh lagi pada saat lokasi balas jasa kompetitif dan sebagian didasarkan pada telaah rekan sejawat, suatu konflik kepentingan yang serius dapat tercipta. Jika seorang prajurit ingin memperbesar kemungkinannya memperoleh balas jasa, proses tinjauan dan rekan sejawat memberikan sesuatu alat untuk menyabotasi kompetisi. Kondisi-kondisi yang dibutuhkan agar penilaian rekan sejawat berlangsung dengan mulus adalah: a) Tingkat kepercayaan antar pribadi yang tinggi. b) Sistem imbalan yang kompetitif. c) Kesempatan-kesempatan bagi rekan sejawat untuk mengamati kinerja satu dengan lainnya. Pada saat kondisi-kondisi tersebut tidak terpenuhi, penggunaan kerabat kerja sebagai evaluator akan memberikan hasil-hasil yang terbatas. Organisasi dengan kelompok-kelompok kerja yang dikelola sendiri besar 
kemungkinannya menggunakan evaluasi rekan sejawat dan pada tanpa kelompok-kelompok seperti itu. Kelompok kerja yang dikelola sendiri dan dewasa sering diserahi tanggung jawab yang biasanya dicadangkan bagi manajer,. termasuk penilaian kinerja. Terdapat beberapa keuntungan untuk telaah rekan sejawat dalam kelompok kerja yang dikelola sendiri. Hubungan kerja yang erat diantara anggota-anggota memastikan bahwa kineija secara berkelanjutan dipantau dan tersedia cukup informasi untuk mendukung suatu penilaian. Kelompok terikat pada tujuan tertentu dan dapat menilai secara rutin apakah setiap anggota berkontribusi sebagaimana seharusnya terhadap tujuan tersebut. Kelompok dapat memberikan umpan balik secara berkelanjutan dan mempengaruhi kinerja melalui tekanan rekan sejawat. Sistem imbalan melalui rekan kerja yang terkelola sendiri dirancang untuk memberikan imbalan bagi produktivitas kelompok sehingga hanya sedikit persaingan individu untuk mengkompromikan validitas penilaian meskipun terdapat kelebihan evaluasi rekan sejawat. Adalah penting menyadari bahwa dalam sebuah kelompok yang belum dewasa atau dalam sistem imbalan yang individual kompetitif, evaluasi rekan sejawat dapat menciptakan banyak masalab. Masalah-masalah itu dapat meliputi banyak tekanan, perselisihan, perpecahan, sikap negatif motivasi kerja yang menurun dan menurunnya produktivitas. 4) Bawahan, Penilaian oleh bawahan dapat menjadi masukan yang berguna bagi pengembangan atasan langsungnya. Bawahan mengetahui dan sumber pertama sesungguhnya atasan memberikan delegasi, seberapa baik -dia berkomunikasi, gaya kepemimpinan yang paling digemari, dan tingkatan dia mereneanakan dan mengorganisasi bawahan-bawahannya. Penilaian oleh bawahan digunakan secara teratur di universitas atau pada beberapa organisasi besar dimana pimpinan memiliki banyak bawahan. Dalam organisasi kecil, atau dalam situasi dimana pimpinan memiliki beberapa bawahan, adalah mudah mengidentifikasi siapa mengatakan apa. Dengan demikian, kepercayaan dan keterbukaan sangatlah penlu sebelum penilaian bawahan membuahkan hasil. Seperti pada evaluasi rekan-rekan sejawat, evaluasi bawahan pada umumnya digunakan bersamaan dengan sumber lainnya dan informasi penilaian kinerja. Hal ini khususnya penting agar tidak mengkaitkan kompensasi dan promosi seorang manajer terlampau dekat dengan penilaian-penilaian oleh bawahan. Bawahan menggelembungkan penilaian mereka atas atasannya, terutama jika mereka menganggap atasannya akan mampu melihat siapa yang memberikan penilaian tertentu. Anonimitas penilaian benar-benar dibutuhkan dalam penilaian ini saluran komunikasi yang terbuka dan kepercayaan diantara atasan dan para bawahan juga dibutuhkan dalam teknik penilaian ini agar berfaedah. Evaluasi oleh bawahan berfaedah bagi pengembangan namun secara historis kurang digunakan secara luas untuk keputusan evaluatif atau administratif. 5) Klien yang dilayani, Dalam beberapa situasi, konsumen dan seorang individu atau jasa organisasi dapat memberikan perspektif yang unik atas kinerja pekerjaan. Contohnya; layanan jasa TV kabel, pelanggan bank, pelanggan jasa pialang dan pasien rumah sakit. Meskipun tujuan klien tidak dapat diharapkan sangat serasi dengan tujuan-tujuan organisasi, informasi yang diberikan oleh klien dapat memberikan informasi yang berguna untuk keputusan personalia, seperti yang berhubungan promosi,, transfer dan kebutuhan pelatihan, informasi ini juga dapat digunakan untuk menilai dampak pelatihan atau sebagai basis bagi pengembangan diri. 6) Komputer, Para prajurit menghabiskan sebagian besar waktunya tanpa diawasi oleh atasan mereka. Saat ini teknologi telah membuat pengawasan yang terus menerus menjadi mungkin. Jenis teknologi apa? Perangkat lunak komputer yang memantau kinerja prajurit. Komputer mempunyai beberapa peran dalam penilaian kinerja. Pertama terdapat paket-paket perangkat lunak yang 
memberikan bantuan bagi proses evaluasi, kedua karena semakin banyak prajurit yang menggunakan komputer sebagai bagian aktivitas pekerjaannya, komputer tersebut menjadi terlibat dalam proses evaluasi. Pemantauan kinerja dengan menggunakan komputer adalah pengukuran langsung atas pekerjaan memungkinkan manajer mengetahui prajunt yang baik. Pemantauan melaui komputer juga memungkinkan para prajurit menetapkan tujuan-tujuan yang realistik dan memberikan umpan batik atas kemajuannya. 7) Penilaian 360 derajat, Banyak oganisasi yang telah menerapkan penilaian-penilaian 360 derajat, dimana penilaianpenilaian kinerja dikumpulkan secara simultan dan bawahan, rekan sejawat, atasan karyawan itu sendiri. Biasanya penilaian 360 derajat digunakan untuk tujuan pengembangan dan umpan balik. Fokus metode ini adalah evaluasi kompetensi-kompetensi yang relevan untuk pelaksanaan pekerjaan dalam istilah-istilah keperilakuan yang berfaedah. Metode ini paling berhasil didalam organisasi yang menawarkan iklim organisasional yang terbuka dan partisipasif serta pengembangan karir yang aktif. 8) Penilaian Sendiri, Dalam sebagian besar prosedur evaluasi kinerja, atasan langsung bertanggung jawab atas evaluasi prajuritnya. Kendatipun para atasan memikul tanggung jawab utama, orang lain hendaknya disertakan pula dalam prosedur penilaian ini. Orang lain yang dimaksudkan adalah bawahan, pelanggan, kerabat kerja dan lainnya.

\section{Pengukuran dan Kinerja}

Beberapa cara yang digunakan untuk mengukur kinerja adalah sebagai berikut: 1) Mengukur berdasarkan skala grafis, Cara ini dilakukan dengan pemberian formulir kepada setiap prajurit, berisikan data sifat dan ciri prestasi kerja yang akan dinilai, dalam skala gratis, skala penilaian dibedakan atas seberapa tepat kategori itu didefinisikan, sampai seberapa jauh tingkat ketelitian prajurit dalam suatu bidang pekerjaan. Untuk menentukan prestasi kerja prajurit, maka kategori yang terbaik adalah dengan menemukan sedikitnya tingkat kegagalan dan meningkatnya jumlah produksi maka prajurit tersebut dapat diberikan imbalan yang sesuai menurut ketentuan organisasi. 2) Penggunaan peringkat, Prosedur ini biasanya mencakup penilaian prajurit yang berhasil mengerjakan suatu tugas dan prajurit yang gagal dalam menyelesaikan tugas. Prajurit yang berhasil menyelesaikan tugas dengan baik, akan mendapat imbalan sesuai ketentuan organisasi sedangkan prajurit yang mengalami kegagalan dapat diberikan sanksi-sanksi menurut aturan organisasi. 3) Daftar cek yang diberikan bobot (Cheklist), Penilaian berdasarkan pembobotan ini terdiri atas sejumlah kriteria yang ditetapkan oleh organisasi untuk diberikan penilaian bagi setiap prajurit. Prajurit yang mempunyai nilai tertinggi adalah prajurit yang berhasil memenuhi kriteria yang ditetapkan oleh organisasi. 4) Evaluasi pekerjaan, Pengukuran prestasi ini dilakukan dengan cara, prajurit yang dinilai diharuskan mengikuti ujian tertulis. Maksudnya adalah untuk mengetahui tingkat kemampuan prajunt baik terhadap pengetahuan di bidang pekerjaannya maupun mengenai pengetahuan umum. 5) Output yang dihasilkan prajurit, Cara pengukuran ini, yaitu dengan menilai jumlah produksi yang dihasilkan oleh prajurit baik produksi jasa maupun produksi barang. Aspek dan model pengukuran prestasi prajurit $i$, adalah untuk mengetahui sampai sejauh mana masingmasing prajurit menunjukkan, kualitas yang diperlukan bagi suatu organisasi. Maksud penilaian ini untuk membantu prajurit agar semakin banyak mengerti tentang peranannya dan mengetahui fungsi organisasi secara jelas. Dengan mekanisme seperti ini maka hubungan antara prajurit dan penyelia akan bertambah baik, sehingga para prajurit dapat mengetahui 
harapan- harapan dan pimpinannya dan pimpinan pun dapat mengetahui kesulitan- kesulitan bawahannya serta berusaha mengatasinya.

Adapun tujuan dan pengukuran prestasi kerja prajurit adalah sebagai berikut: a) Mengetahui keadaan ketrampilan dan kemampuan setiap prajurit secara intim. b) Untuk digunakan sebagai dasar perencanaan dibidang personalia dan hasil kerja. c) Dapat digunakan sebagai dasar pengembangan dan pendayagunaan prajurit secara optimal. d) Mendorong terciptanya hubungan timbal balik yang sehat.

Sehubungan dengan penjelasan mengenai penilaian kinerja, penilaian ini dilakukan oleh komandanlatasan langsung dan prajurit yang bersangkutan. Indikator-indikator kesuksesan prajurit dalam melakukan tugas/pekerjaan tercermin pada ukuran-ukuran yang telah ditetapkan setelah dikonsultasikan dengan para pimpinan di lingkungan Lantamal II. Ukuran-ukuran yang digunakan sebagai berikut: kualitas kerja, kuantitas kerja waktu kerja, kerjasama, dan pengawasan.

\section{METODE}

Dalam metodologi penelitian ini disajikan metode yang digunakan memecahkan permasalahan dengan objek pengamatan penelitian di lingkungan Lantamal II.Metode penelitian ini meliputi: populasi dan sampel, teknik pengolahan data, teknik analisis.

Penelitian menggunakan pendekatan Explanatory analysis. Artinya setiap variabel yang diketengahkan pada hipotesis akan diamati melalui pengujian hubungan kausal antara variabel independent terhadap variabel dependent. Dalam hal ini mengkaji hubungan antara dua variabel atau lebih, dimana dalam penelitian ini mengkaji hubungan dan pengaruh antara faktor kemampuan dan motivasi terhadap kinerja prajurit di lingkungan Lantamal II

Populasi yang menjadi objek pengamatan ini adalah para prajurit di lingkungan Lantammal II yang diperlakukan sama oleh pihak organisasi dianggap mewakili populasi yang berjumlah 42 responden.

\section{HASIL DAN PEMBAHASAN}

\section{Tabel - 1: Pengaruh Simultan Kemampuan dan Motivasi Terhadap Kinerja Prajurit di Lingkungan Lantamal II}

\begin{tabular}{|c|c|c|c|c|c|c|c|c|}
\hline \multirow{2}{*}{$\begin{array}{c}\text { Hubungan } \\
\text { Variabel }\end{array}$} & \multicolumn{8}{|c|}{ Paramter } \\
\hline & $\begin{array}{c}\text { Mult. } \\
\text { R }\end{array}$ & $\begin{array}{c}\mathbf{R} \\
\text { Square }\end{array}$ & $\begin{array}{c}\mathbf{t} \\
\text { hitung }\end{array}$ & $\begin{array}{c}\text { t } \\
\text { tabel }\end{array}$ & Konstanta & $\begin{array}{c}\text { Coef. } \\
\text { B }\end{array}$ & Sig & $\boldsymbol{\alpha}$ \\
\hline Kemampuan & \multirow{2}{*}{0.919} & \multirow{2}{*}{0.844} & 3,690 & \multirow{2}{*}{2,021} & \multirow{2}{*}{24,850} & $\mathbf{0 , 4 8 3}$ & \multirow{2}{*}{0,000} & \multirow{2}{*}{$5 \%$} \\
\hline Motivasi & & & 2,501 & & & $\mathbf{0 , 3 2 1}$ & & \\
\hline \multicolumn{9}{|c|}{ Pengujian Signifikan } \\
\hline & & $3>3$ & & & & & & \\
\hline
\end{tabular}

Keterangan: Variabel Kinerja Prajurit

Sumber: data diolah tahun 2013 
Berdasarkan nilai koefisien korelasi pada tabel di atas, hubungan yang terbentuk sangat kuat dan berprediksi positif.Dengan memperhatikan model simultan maka persamaan yang dapat dijelaskan adalah sebagai berikut:

$$
Y=24,850+0,483 X_{1}+0,321 X_{2}+e .
$$

Didasarkan pada persamaan di atas, faktor kemampuan berprediksi positif $(+)$ dengan koefisien kemampuan $0,483 \mathrm{X}_{1}$ dan faktor motivasi berprediksi positif $(+)$ dengan koefisien motivasi $0,321 \mathrm{X}_{2}$ melihat perolehan model dapat dikatakan bahwa faktor kemampuan lebih dominan dibanding faktor motivasi.

Lebih jauh, ternyata hubungan simultan yang kuat dan berprediksi positif tersebut terjadi secara signifikan. Jika F sig $<\alpha(0,05)$ maka Ho diterima dan Ha ditolak, artinya hubungan terjadi secara signifikan. Kemudian perhatikan perolehan $\mathrm{F}$ hitung sebesar 13,893 dan nilai $\mathrm{F}$ sig $=0,000$ untuk alfa $(\mathrm{a})=0,05$, maka dapat dinyatakan bahwa hubungan simultan ini terjadi secara signifikan dengan 13,893 $>0,000<0,05$.

Berkenaan dengan pembenaran hipotesis tersebut dapat dijelaskan bahwa faktor kemampuan yang selama ini dijalankan di lingkungan Lantamal II telah menyebabkan meningkatnya kompetensi para prajurit itu sendiri. Peningkatan kemampuan para prajurit ini dibarengi dengan peningkatan pendidikan, pelatihan- pelatihan yang diikuti yang relevan dengan pelaksanaan tugas serta meningkatnya pengalaman prajurit itu sendiri. Diharapkan dengan peningkatan kemampuan para prajurit akan dapat mendorong motivasi kerja yang pada gilirannya juga mampu meningkatkan kinerja individu dan pada prajurit itu sendiri.

\section{Tabel - 2: Pengaruh Parsial Kemampuan Terhadap Kinerja Prajurit di Lingkungan Lantamal II}

\begin{tabular}{|c|c|c|c|c|c|c|c|c|}
\hline \multirow{2}{*}{$\begin{array}{c}\text { Hubungan } \\
\text { Variabel }\end{array}$} & \multicolumn{9}{|c|}{ Paramter } \\
\cline { 2 - 9 } & $\begin{array}{c}\text { Mult. } \\
\text { R }\end{array}$ & $\begin{array}{c}\mathbf{R} \\
\text { Square }\end{array}$ & $\begin{array}{c}\mathbf{t} \\
\text { hitung }\end{array}$ & $\begin{array}{c}\mathbf{t} \\
\text { tabel }\end{array}$ & Konstanta & $\begin{array}{c}\text { Coef. } \\
\mathbf{B}\end{array}$ & Sig & $\boldsymbol{\alpha}$ \\
\hline Kemampuan & $\mathbf{0 . 9 3 1}$ & $\mathbf{0 . 8 6 7}$ & $\mathbf{3 , 1 9 8}$ & $\mathbf{2 , 0 2 1}$ & $\mathbf{2 4 , 0 7 9}$ & $\mathbf{0 , 2 8 5}$ & $\mathbf{0 , 0 0 0}$ & $\mathbf{5 \%}$ \\
\hline
\end{tabular}

Keterangan: Variabel Kinerja Prajurit

Sumber: data diolah tahun 2013

Secara parsial faktor kemampuan memiliki korelasi atau hubungan yang sangat erat terhadap kinerja prajurit, hal ini ditujukan dengan koefisien korelasi (R) sebesar 0,931 atau sebesar 93,1\%. Di lihat dari R Square pengaruhnya sangat kuat yakni sebesan $86,7 \%$ sedangkan sisanya sebesar $13,3 \%$ dipengaruhi oleh faktor-faktor lain di luar model yang diamati.

Hubungan yang sangat kuat sebagaimana dijelaskan di atas, ternyata berprediksi positif.perhatikan model parsial yang dihasilkan $\mathrm{Y}=24,079+0,285 \mathrm{X}_{1}+\mathrm{e}$. Hal ini menyatakan bahwa terdapat hubungan yang sangat kuat dan berprediksi positif tersebut terjadi secara signifikan. Hal ini dapat dilihat dan perolehan $t$ hitung yang dihasilkan $>t$ signifikan atau $3,198>0,000$ untuk alfa $(a)=0,05$, maka dapat dinyatakan bahwa hubungan ini terjadi secara signifikan. 
Berkenaan dengan pembenaran hipotesis tersebut dapat dijelaskan bahwa faktor kemampuan yang selama ini melekat pada diri prajurit di lingkungan Lantamal II telah mampu meningkatkan kinerja para prajurit.

Tabel - 3: Pengaruh Parsial Motivasi Terhadap Kinerja Prajurit di Lingkungan Lantamal II

\begin{tabular}{|l|c|c|c|c|c|c|c|c|}
\hline \multirow{2}{*}{$\begin{array}{c}\text { Hubungan } \\
\text { Variabel }\end{array}$} & \multicolumn{10}{|c|}{ Paramter } \\
\cline { 2 - 9 } & $\begin{array}{c}\text { Mult. } \\
\mathbf{R}\end{array}$ & $\begin{array}{c}\mathbf{R} \\
\text { Square }\end{array}$ & $\begin{array}{c}\mathbf{t} \\
\text { hitung }\end{array}$ & $\begin{array}{c}\mathbf{t} \\
\text { tabel }\end{array}$ & Konstanta & $\begin{array}{c}\text { Coef. } \\
\mathbf{B}\end{array}$ & Sig & $\boldsymbol{\alpha}$ \\
\hline Motivasi & $\mathbf{0 , 8 2 9}$ & $\mathbf{0 , 6 8 7}$ & $\mathbf{3 , 4 1 1}$ & $\mathbf{2 , 0 2 1}$ & $\mathbf{2 9 , 9 0 7}$ & $\mathbf{0 , 4 5 4}$ & $\mathbf{0 , 0 0 0}$ & $\mathbf{5 \%}$ \\
\hline
\end{tabular}

Keterangan: Variabel Kinerja Prajurit

Sumber: data diolah tahun 2013

Secara parsial faktor motivasi memiliki korelasi atau hubungan yang sangat erat terhadap kinerja prajurit, hal ini ditujukan dengan koefisien korelasi (R) sebesar 0,829 atau sebesar 82,9\%. Di lihat dari R Square Pengaruhnya cukup kuat yakni sebesar 68,7\% sedangkan sisasnya sebesar 31,3\% dipengaruhi oleh faktor-faktor lain di luar model.

Hubungan yang cukup kuat sebagaimana dijelaskan diatas, ternyata berprediksi positif perhatikan model yang dihasilkan adalah $\mathrm{Y}=29,907+0,454 \mathrm{X}_{2}$. Hal ini menyatakan bahwa terdapat hubungan parsial yang cukup kuat dan berprediksi positif tersebut terjadi secara signifikan. Hal ini dapat dilihat dan perolehan $t$ hitung yang dihasilkan $>t$ signifikan atau $3,411>0,000$ untuk alfa (a) $=0,05$, maka dapat dinyatakan bahwa hubungan ini terjadi secara signifikan.

Mengacu dan uraian di atas, maka dugaan bahwa secara parsial faktor motivasi berpengaruh positif dan signifikan terhadap kinerja prajurit dapat dianggap tepat. Motivasi mendorong seseorang untuk berbuat sesuatu Perbuatan ada dua macam yaitu pemikiran dan tindakan. pemikiran adalah perbuatan rohani yang menghendaki bekerjanya daya pikir manusia, sedangkan tindakan adalah perbuatan jasmani terutama membutuhkan gerak otot tubuh manusia. Dengan demikian suatu tindakan (termasuk bekerja dengan giat) ialah suatu perbuatan jasmani yang mengandung suatu tujuan/harapan/keinginan tertentu yang memang dikehendaki oleh orang yang melakukan tindakan itu. Dorongan dan harapan dari dalam prajurit baik untuk mendapatkan pengakuan, untuk mendapatkan pengembangan, untuk mendapatkan lingkungan yang menyenangkan dan untuk mendapatkan lingkungan yang menyenangkan dan untuk mendapatkan hubungan yang harmonis serta untuk meningkatkan kesejahteraannya membuat para prajurit di lingkungan Lantamal II bekerja lebih giat.

\section{KESIMPULAN DAN SARAN}

\section{Kesimpulan}

Dari hasil pembahasan tersebut di atas, menunjukkan bahwa terdapat pengaruh faktor kemampuan dan motivasi terhadap kinerja prajurit di lingkungan Lantamal II.Berdasarkan 
penelitian yang telah dilakukan diperoleh kesimpulan sebagai berikut: 1) Secara simultan variabel kemampuan dan motivasi memiliki hubungan yang sangat erat yakni sebesar 91,9\% dengan kontribusi sebesar 84,4\% terhadap kinerja prajurit di lingkungan Lantamal II. Dimana hubungan ini berprediksi positif dan terjadi secara signifikan.2) Secara parsial faktor kemampuan memiliki kontribusi sebesar 86,7\% terhadap kinerja prajurit di lingkungan Lanntaal II. Dimana hubungan ini berprediksi positif dan terjadi secara signifikan.3) Secara parsial variabel motivasi memiliki kontribusi sebesar $68,7 \%$ terhadap kinerja prajurit di lingkungan Lantamal II. Dimana hubungan ini berprediksi positif dan terjadi secara signifikan

\section{Saran}

Berdasarkan kesimpulan tersebut, maka saran-saran yang dapat direkomendasikan adalah sebagai berikut: Berdasarkan analisis dan pembahasan faktor kemampuan yang selama ini melekat atau dimiliki para prajurit dapat membentuk kinerja prajurit di lingkunngan Lanntamal II, dengan demikian hendaknya kemampuan para prajurit pada masa yang akan ditingkatkan. Upaya peningkatan kemampuan para prajurit ini dapat ditempuh baik melalui pendidikan formal, mengikuti pelatihan-pelatihan yang relevan dengan pelaksanaan tugas serta peningkatan pengalaman kerja.

\section{DAFTAR PUSTAKA}

Bernardin, H.J, and Joyce E.A. Russell, Human Resource Management, New York, Mc Graw Hill, Inc, 2003

Blum M.I, and Naylor, J.C, Industrial Psychology, Ins Teoritical and Social Fondation, New York, Herper and Row Publisher, 2001

Dessler, Gray, Human Resource Management, Seven Edition, Prentice Hall, Inc, New Jersey, 2002

Emory, R. Cooper, Business Research Method, $4^{\text {th }}$ Edition, Richard D Irwin, Inc, USA, 2000

Flippo, Edwin B, Manajemen Personalia, Jilid II, Alih Bahasa: Moh. Masud, Erlangga, Jakarta, 2001

Gordon, Judith R. A diagnostic Approach to Organizational Behavior, USA, Allyn and Bacon, 2003

Hadi Poernomo, Tata Personalia, Penerbit Jembatan, 2003

Gibson, James L, Organisasi: Perilaku, Struktur dan Proses, Jilid I, Edisi V, Alih Bahasa: Djakarsin, Erlangga, Jakarta, 2002

Handoko, T. Hani, Manajemen Personalia dan Sumberdaya Manusia, Edisi 2, BPFE, Yogyakarta, 2004

Hasan Iqbal, Analisis Data Penelitian Dengan Statistik, Bumi Aksara, Jakarta, 2004

Herzberg. F, Mausner, B. And Synderman. BB, The Motivation to Work, Second Edition, New York, John Willey and Sons Inc, 2003

Kast FE, Rosenzweig, JE, Organisasi dan Manajemen, Terjemahan, Penerbit Bumi Aksara, Jakarta, 2004 
Locke E.A, The Nature and Causes of Job Satisfacations, in MD, Dunnete (ed), Handbook of Industrial and Organizational Psychography, Chicago, Rand Mc, Nally, 2002

Luthans, Fred, Organizational Behavior, Fifth Edition, Singapore, Mc. Graw Hill International, 2000

Milkovich, Georet, and John W. Boudreau, Human Resource Management, Sixth Edition, USA, RR Donelly \& Sons Company, 2001

Martoyo Susilo, Manajemen Sumberdaya Manusia, BPFE, Yogyakarta, 2000

Miner, Johnn B, Organizational Behavior, Performance and Productivity, First Edition, Random House Inc, 2000

Ranupandoyo, Heidjrachman, Manajemen Personalia, Cetakan Pertama, Edisi Revisi, BPFE, Yogyakarta, 2001

Robbins, Stephen P, Organization Behavior, Prentice Hall International, Singapore, 2004

Sarwono, Jonathan, Analisis Data Penelitian Menggunakan SPSS 14, Penerbit Anddi, Yogyakarta, 2006

Siagian P, Sondang, Manajemen Sumberdaya Manusia, Jilid 1, Cetakan Kedua, Gunung Agung, Jakarta, 2001

Singaribuan Masri, Metode Penelitian Survey, LP3ES, Jakarta, 2004

Sugiyono, Metode Penelitian Bisnis, Alfabeta, Bandung, 2007

Suharyadi dan Purwanto, Statistika Untuk Ekonomi dan Keuangan Modern, Salameba Empat, Jakarta, 2004

Stoner, James AF, and Edward Freeman, Management, Forth Edition, Englewood Chiffs, New Jersey, 2000

Umar, Husein, Riset Sumber Daya Manusia Dalam Organisasi, Cetakan ketiga, PT. Gramedia Pustaka Utama, Jakarta, 2003 